\title{
Application of Mohs Surgery to the Treatment of Basosquamous Cell Carcinoma Originating from the Auricle
}

\author{
Keun-Ik Yi, Soo-Keun Kong, Eui-Kyung Goh, and Se-Joon Oh \\ Department of Otorhinolaryngology-Head and Neck Surgery, Pusan National University Hospital, \\ Pusan National University School of Medicine and Medical Research Institute, Busan, Korea
}

\author{
이개에 발생한 기저편평세포암의 치료에서 Mohs 미세도식수술의 적용 \\ 이근익 · 공수근 · 고의경 · 오세준 \\ 부산대학교 의과대학 부산대학교병원 이비인후과학교실
}

\author{
Received October 18, 2016 \\ Revised November 23, 2016 \\ Accepted November 23, 2016 \\ Address for correspondence \\ Se-Joon Oh, MD, PhD \\ Department of Otorhinolaryngology- \\ Head and Neck Surgery, \\ Pusan National University Hospital, \\ Pusan National University \\ School of Medicine and \\ Medical Research Institute, \\ 179 Gudeok-ro, Seo-gu, \\ Busan 49241, Korea \\ Tel +82-51-240-7336 \\ Fax +82-51-246-8668 \\ E-mail o3jdoc@hanmail.net
}

\begin{abstract}
Complete removal is most important in treating the malignant tumor from the auricle, but the cosmetic and reconstructive plan after removal should also be considered because auricular appearance contributes enormously to the facial aesthetics. Mohs micrographic surgery (MMS), which is commonly used in dermatology, is considered as minimal marginal surgery that offers superior cure rates in the treatment of facial skin cancer. Therefore, MMS could provide a minimally invasive way to manage the malignant tumor of the auricle. This article reports that basosquamous cell carcinoma arising in the auricle was treated with wide resection combined with MMS. Conclusively, we could accomplish the surgical purpose of both completely removing the tumor and maintaining the auricular aesthetic shape by additionally introducing MMS in the treatment.

Korean J Otorhinolaryngol-Head Neck Surg 2018;61(4):212-6
\end{abstract}

Key Words Auricle $\cdot$ Basosquamous cell carcinoma $\cdot$ Mohs'surgery.

\section{서 론}

이개는 깔대기 모양의 연골구조물로서 얇은 탄성연골이 골 격을 이루며 그 위를 연골막, 피하 조직과 얇은 피부가 덮고 있다. 연골 골격은 심한 요철을 이루는 복잡한 구조이면서 외형적으로 가장 노출된 부위이므로 귀 변형이나 외상 시 귀 성형의 대상이 된다.1) 따라서 이개에 발생한 병변을 수술하 는 경우 병변의 완전제거뿐만 아니라 제거 후 미용 및 재건을 더욱 고려해야 한다.

귀에 발생하는 암종은 조직학적으로 기저세포암종과 편평

This is an Open Access article distributed under the terms of the Creative Commons Attribution Non-Commercial License (http://creativecommons.org/licenses/by-nc/4.0) which permits unrestricted non-commercial use, distribution, and reproduction in any medium, provided the original work is properly cited.
세포암종이 가장 흔하고 그 외에 흑색종, 선양낭성암종, 선암 종, 육종 등이 발생한다. 귀에 발생하는 암종의 부위별 빈도 는 이개 $68 \%$, 외이도 $22 \%$, 중이 및 내이 $10 \%$ 로 이개에 가장 흔히 발생하며, 이개의 원발성 악성종양은 전체 피부암의 약 $6 \%$ 정도를 차지한다.

안면부 피부암을 제거하기 위한 수술은 그 복원이 기능 및 미용적으로 매우 중요하다. 안면 피부암의 치료목표는 안면 의 기능이나 외모에 지장을 주지 않고 종양이 재발하지 않도 록 완전히 제거하는 것이다. 하지만 귀에 발생하는 암을 제거 하기 위해 안전역을 두고 수술한다면 종양의 크기에 따라 귀 의 변형 및 미적인 문제가 발생할 수 있다. Mohs 미세도식수 술(Mohs micrographic surgery)은 기저세포암 및 편평세포암 등 안면 피부암에 있어 $97 \%$ 이상의 높은 완치율을 보이면서 
도 최소한의 병변만을 제거할 수 있는 치료법으로 알려져 왔 다. ${ }^{3)}$ 따라서 이개에 발생하는 악성종양 수술에서 Mohs 미세 도식수술을 함께 적용함으로서 병변의 완전제거와 미용학적 목적을 함께 달성할 수 있을 수 있다.

본 증례에서는 이개에서 발생하여 외이도 연골부를 침범 한 기저편평세포암의 치료에서 Mohs 미세도식수술을 병행 함으로서 최소침습적인 치료를 할 수 있었던 1예를 보고하고 자 한다.

\section{증 례}

41세 백인 남자 환자가 1년 전부터 좌측 이개에 발생한 궤양 성 홍반을 주소로 본원에 내원하였다. 3년 전부터 이개의 소 양감이 있었으며 내원 당시 이통 증상을 호소하였고 과거력 상 폐색전증으로 호흡기내과 약물치료를 받고 있는 것 외에 특 이 소견은 없었다. 본원 피부과에서 국소 마취하에 시행한 절 개 생검을 시행하였으며, 조직검사 결과 편평세포암으로 진단 되어 수술적 치료를 위해 이비인후과에 의뢰되었다. 신체 검 사상 좌측 이갑개강 및 이갑개주 부위에 궤양성 홍반성 종
물이 외이도 후외측 부위를 일부 막고 있는 양상으로 관찰되 었고 그 주변으로 이륜 전각 및 대이륜 부위로 흑색소가 침 착된 가피가 형성되어 있었다(Fig. 1A). 종물 내부 외이도는 정상 고막 소견이었으며 주위 조직이나 경부에 전이를 의심할 만한 특별한 소견은 관찰되지 않았다. 표준순음청력검사상 정상청력이었으며 전산화단층촬영 및 자기공명영상촬영상 좌측 이륜과 외이도에 우측에 비해 두꺼워진 조영증강된 연조 직 음영의 병소가 관찰되었다. 주변 조직과의 경계는 확실하지 않았으며 외이도 골의 침범은 없는 것으로 확인되었다(Fig. $1 \mathrm{~B}$ and $\mathrm{C}$ ). 양전자방출단층촬영을 시행하였고 좌측 이개에 강한 fluorodeoxyglucose 섭취 소견이 관찰되었으며(standardized uptake value max: 6.4) 타 장기로의 전이소견은 관찰되지 않았다(Fig. 1D).

종양이 이개에서 발생하여 외이도 연골부분까지 차지하고 있어 Mohs 미세도식수술로 종양의 이개 피부범위를 결정하 고, 피부보다 깊은 부위 및 외이도 연골부위는 동결조직생검 결과를 보면서 제거할 것을 계획하였다. 피부과에서 국소 마 취하 Mohs 미세도식수술을 시행하여 종괴 주변으로 절제연 의 암 잔존 여부를 확인하며 절제하였고 Mohs 미세도식수술
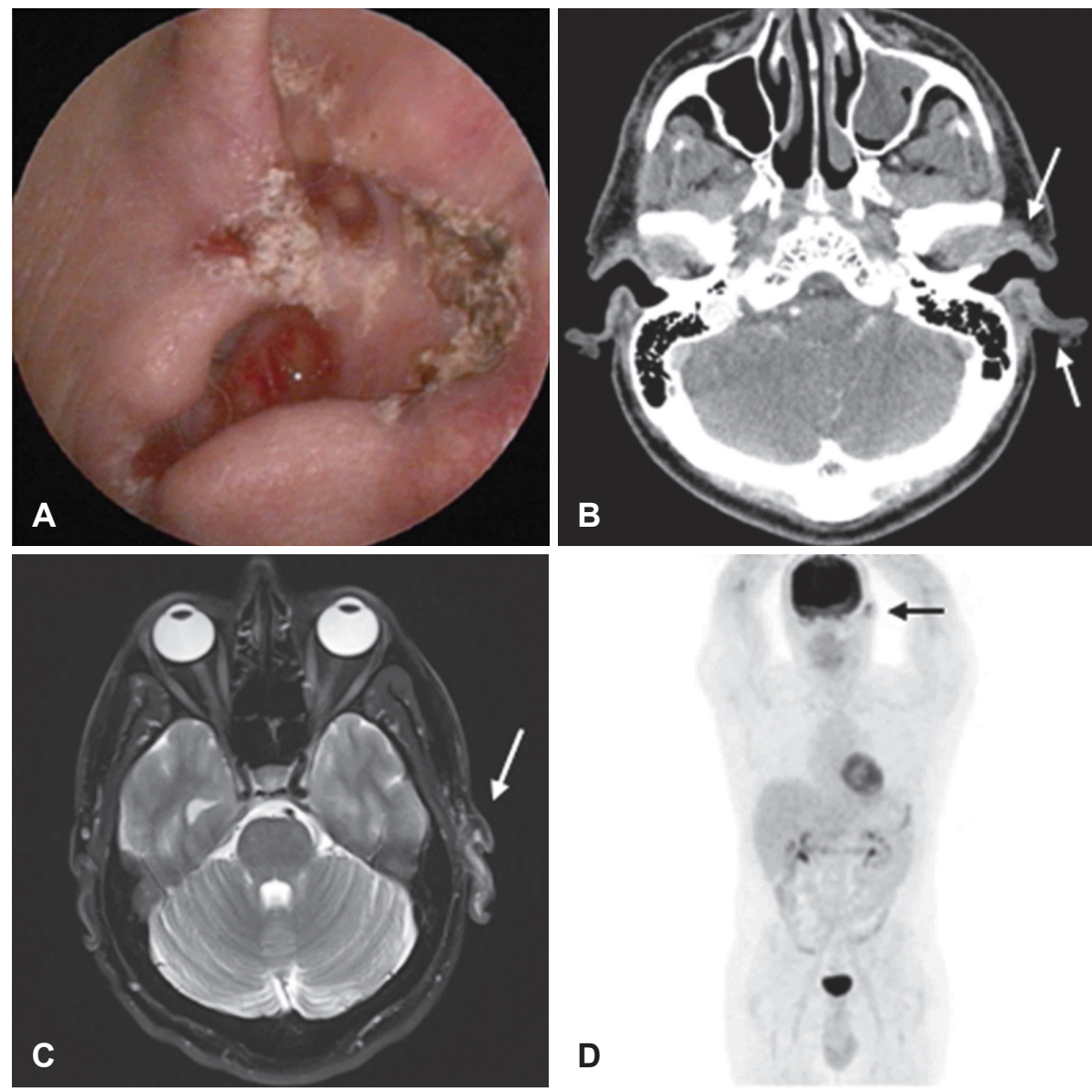

D

Fig. 1. Preperative photograph $(A)$ and radiologic findings $(B, C$, and D) of a 41-year-old male patient. A photograghic images shows ulcerative erythematous patches with some black pigment of left auricle (A). Axial view of temporal soft tissue CT. Mild thickening and enhancement at EAC and helix of left ear (arrows) (B). Axial T2-weighted image. Diffuse T2 high signal intensity lesion with enhancement at left ear auricle and EAC (arrow). No evidence of bony involvement $(\mathrm{C}) .{ }^{18} \mathrm{~F}$ FDG PET/CT scan. Increased FDG uptake at the left auricle (arrow) (SUV max: 6.4). No evidence of systemic metastasis (D). FDG: fluorodeoxyglucose, EAC: external auditory canal, SUV: standardized uptake value. 
로 완전 절제되지 않은 부위에 대한 정보를 제공하였다(Fig. $2 \mathrm{~A})$. 다음날 수술장에서 절제연을 따라 이갑개를 포함하여 광범위절제술을 시행하고 바로 시행한 동결조직생검상 대이륜 및 후하방 외이도에서 종양의 침습을 확인하였다. 이에 대이
륜 연골 및 외이도 연골부를 포함하여 변연절제술을 추가 시 행하였고 변연부에서 종양 침습이 없음을 확인하고 전층 피 부이식 및 국소피판술을 이용하여 절제된 이개를 재건하였 다(Fig. 2B, C, and D). 수술 후 조직검사상 기저편평세포암
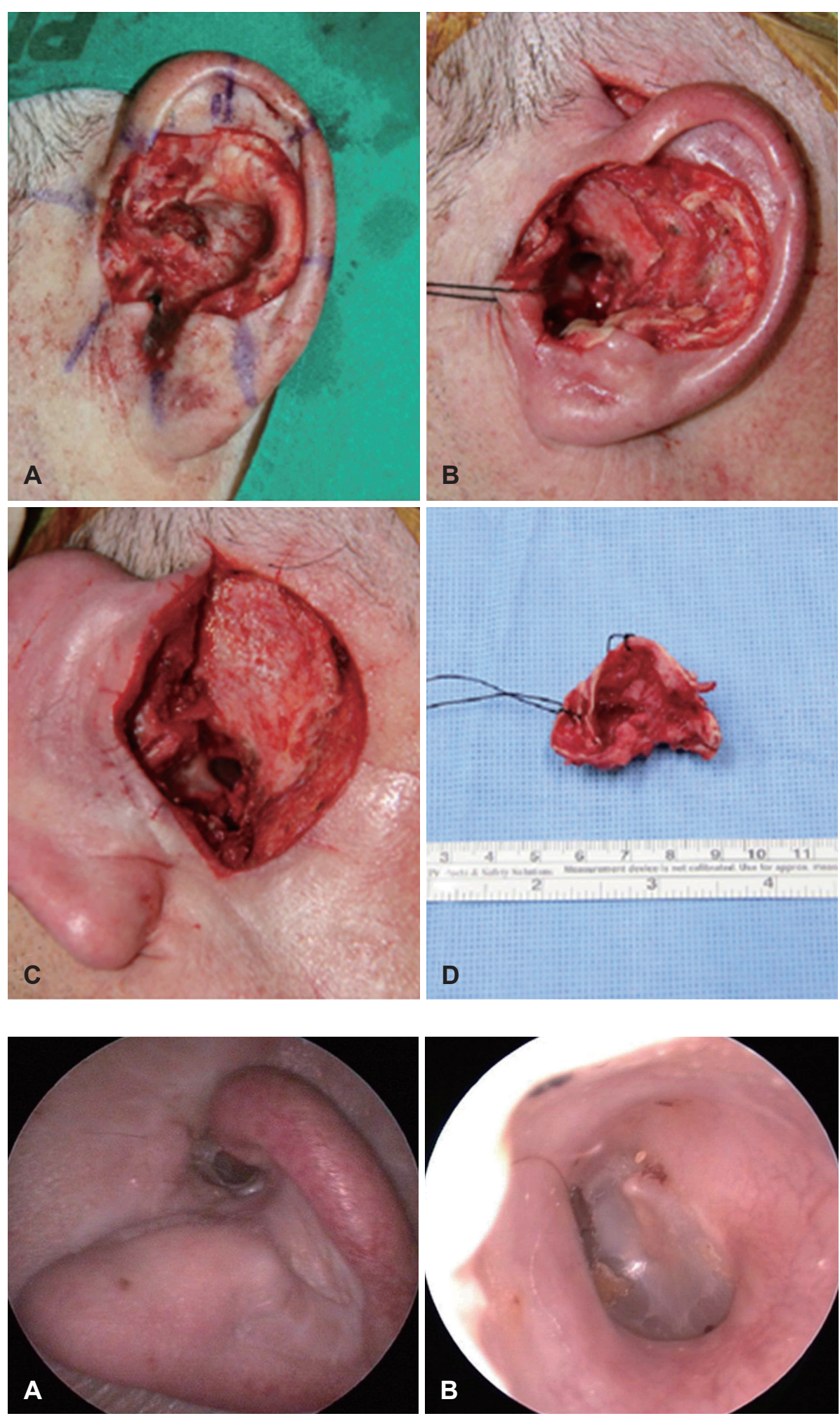

Fig. 3. A year postoperative result following sleeve resection. Left auricle (A) and left external auricular canal (B).
Fig. 2. Intra-operative findings. Mohs micrographic surgery $(A)$ and sleeve resection $(B, C$, and $D)$. 
으로 진단되었고 신경주위 및 림프혈관 침범은 없는 것으로 나타났다. 재발률을 낮추기 위해 술 후 방사선 치료[intensity modulated radiation therapy(IMRT), 25 35회, 50 70 Gy]를 권유하였으나 환자가 거부하여 시행하지 못하고 이후 외래에 서 경과관찰하였다.

이후 술 후 24개월까지 외래 경과관찰하였으나 현재 재발소 견은 없는 상태이다(Fig. 3).

\section{고 찰}

피부암은 인체에서 가장 많은 발생 비율을 차지하는 악성 종양으로 노인 인구의 증가, 환경오염과 오존층의 파괴, 생활 양식의 변화와 연관되어 각종 유해물질 및 일광에 노출될 기 회가 많아지면서 그 발생 빈도가 증가하고 그 양상이 다양해 지고 있는 실정이다. 주로 자외선에 노출되는 안면, 경부, 두피 등에 호발하며 그중 안면부에 가장 호발하는 것으로 알려져 있다. 이 중 기저세포암과 편평세포암이 가장 흔하다고 알려 져 있으며 전체 피부암 중 기저세포암이 약 $77 \%$, 편평세포암 이 약 $20 \%$ 에 이른다고 보고하고 있다. ${ }^{3)}$ 이개 혹은 외이도의 종양은 대개 무통성 종물로써 자라면서 동통, 소양감 또는 경도의 출혈이 생기기도 한다.2)

기저편평세포암은 기저세포암의 아형으로 조직형태학적으 로 기저세포암과 편평세포암 중간 정도의 악성 신생물로서 공 격적인 성향을 가지고 높은 재발률과 전이율을 보이며, 문헌 에 따르면 유병률은 1.2 2.7\%를 차지한다. ${ }^{4.5)} 50$ 80대까지의 백인 남성에서 주로 발생하며 $97 \%$ 가 두경부에서 호발하고 특히 중앙안면부 또는 이개에서 발생이 흔하다. ${ }^{67)}$ 몇몇 저자 는 편평세포암과 비슷한 성향을 가진다고도 보고하였다. ${ }^{899}$ 기저편평세포암의 전이율은 5 8.4\%이고 이것은 편평세포암 과 유사하다. ${ }^{5)}$ 재발의 예후인자로는 남성, 암절제연 양성, 림 프관침윤, 신경주위침윤 등이다. ${ }^{7)}$

기저편평세포암의 임상 및 조직학적 진단은 어려운데 임상 적으로 보통 다른 형태의 기저세포암이나 평편세포암처럼 천 천히 자라며 조직학적으로는 고형의 기저세포암보다 크고, 창 백하고 더 둥근 전형적인 기저양 세포와 풍부한 호산성 세포 질로 구성된 편평양 세포 모두 가지고 있다. ${ }^{10)}$ 처음 조직검사 로 기저편평세포암의 정확한 진단 확률은 $13.7 \%$ 로 매우 낮으 며, ${ }^{6}$ 표재적 또는 부분적 조직검사는 기저세포암 또는 편평세 포암으로 오진할 수 있다. ${ }^{11)}$

치료는 광범위 국소 절제술, 방사선 치료, Mohs 미세도식수 술 등이 있다. ${ }^{12)}$ 종양의 희귀성, 세포성장형태, 초기진단기준 부재로 가장 좋은 치료선택에 대한 연구는 드물며, 때문에 대부분의 피부암에서는 수술적 절제가 최선의 치료법이나
기저 편평세포암의 치료에 있어서는 일반적 치료지침은 확립 되어있지 않다. ${ }^{7)}$

종양의 수술적 제거 시 완치율을 높이기 위해서는 경계부의 침윤 여부를 확인하는 것이 중요한데, 광범위 국소 절제술후 전통적인 조직학 분석 시에는 경계부의 일부만을 관찰하여 판독한다. 피부 악성종양은 주변부로 일정한 성장을 하지 않 기 때문에 기존의 단순 절제술로는 안전역을 정확히 파악할 수 없어 재발률이 높아지는데 이러한 단점을 보완하고자 절 제한 경계부를 $100 \%$ 에 가깝게 관찰하여 불규칙한 모양의 악성종양이라도 이론적으로는 완전 절제가 가능한 방법으로 Mohs 미세도식수술이 도입되었다. ${ }^{13)}$

피부에 발생한 기저평평세포암의 경우 광범위 국소 절제술 은 12.1 45.7\%의 높은 재발률이 보고되고 있는 반면 Mohs 미세도식수술은 $4.1 \%$ 의 5년 국소 재발률을 보였으며 5년 무 재발생존율은 $95.1 \%$ 이고 이것은 기존의 수술적 제거술에 비 해 현저히 낮은 수치이다. ${ }^{11)}$

그 외에 Mohs 미세도식수술은 정상조직을 비교적 많이 보 존할 수 있어 수술 후 반흔이나 기능적 제약을 줄일 수 있으며 특히 안면부와 같이 조직 보존이 필수적인 곳도 Mohs 미세 도식수술의 적응이 된다. ${ }^{14)}$

이처럼 Mohs 미세도식수술은 정밀한 수술 변연부 확인이 가능하기 때문에 높은 치료율을 보이며, 절제로 인해 발생하 는 결손부를 최소화할 수 있다. 이것은 특히 안면부에서 미용 적인 측면뿐 아니라 기능적인 측면에서도 중요하며, 때문에 표층부의 피부암에 있어서 치료율을 높이고 결손부를 최소 화할 수 있는 수술 방법으로 알려져 있다. 그러나 안구 또는 뼈와 같은 피부 외 조직을 침범한 깊은 병변에 있어서는 국소 마취하에 Mohs 미세도식수술을 진행하기에 제한이 있다. ${ }^{15)}$

본 증례에서는 이개에 발생한 악성종양이 진행을 하여 외 이도를 침범하였을 뿐만 아니라, Mohs 미세도식수술에서 이 미 암세포가 일부분에서 귀연골에 침윤되고 있어 Mohs 미세 도식수술 단독으로는 수술을 할 수 없었으나, 절제할 최소한 의 경계면를 결정하는 데는 도움을 얻을 수 있었다. 그 후 침 습 깊이에 대해서는 동결조직생검을 시행하여 더 이상 악성 종양이 관찰되지 않을 때까지 이개 및 외이도의 연골을 제거 하였다. 외이도 골부는 침범하지 않아 측두골 외측절제술 (lateral temporal resection)의 적응증에는 해당되지 않았다. 결론적으로 이개에 발생하는 악성종양일 경우 초기에 침윤 깊이가 깊지 않다면 Mohs 미세도식수술을 이용하여 최소한 의 절제로 미용적, 기능적인 측면에서 많은 이점을 기대할 수 는 있겠으나 종양이 외이도를 침범할 정도로 진행되거나 침윤 깊이를 알 수 없다면 외이도에 발생하는 악성종양에 대한 치 료 원칙에 따라 수술적 방법을 함께 병행해야 할 수 있으며, 
이것이 조직학적으로 공격적인 성향을 가진 암종이라면 절제 연을 충분히 확보해야 재발률을 줄일 수 있을 것이다.

\section{Acknowledgments}

This work was supported by clinical research grant from Pusan National University Hospital in 2017.

\section{REFERENCES}

1) Oh SJ, Goh EK, Kong SK. Anatomy of the external ear and anthropometry. J Clinical Otolaryngol 2012;23:151-7.

2) Lee YJ, Ji YB, Park CW, Tae K. A case of metastatic auricle cancer from gastric adenocarcinoma. Korean J Otorhinolaryngol-Head Neck Surg 2014;57(3):178-81.

3) Park CH, Kim HS, Lee JH, Hong SM, Kwon TK, Jung HH, et al. Clinical study of facial skin cancer. Korean J OtorhinolaryngolHead Neck Surg 2008;51(11):1043-6.

4) Martin RC 2nd, Edwards MJ, Cawte TG, Sewell CL, McMasters KM. Basosquamous carcinoma: analysis of prognostic factors influencing recurrence. Cancer 2000;88(6):1365-9.

5) Bowman PH, Ratz JL, Knoepp TG, Barnes CJ, Finley EM. Basosquamous carcinoma. Dermatol Surg 2003;29(8):830-2; discussion 833 .

6) Leibovitch I, Huilgol SC, Selva D, Richards S, Paver R. Basosquamous carcinoma: treatment with Mohs micrographic surgery. Cancer
2005;104(1):170-5.

7) Volkenstein S, Wohlschlaeger J, Liebau J, Arens A, Lehnerdt G, Jahnke K, et al. Basosquamous carcinoma--a rare but aggressive skin malignancy. J Plast Reconstr Aesthet Surg 2010;63(3):e304-6.

8) Crowson AN. Basal cell carcinoma: biology, morphology and clinical implications. Mod Pathol 2006;19 Suppl 2:S127-47.

9) Garcia C, Poletti E, Crowson AN. Basosquamous carcinoma. J Am Acad Dermatol 2009;60(1):137-43.

10) Vantuchová $Y$, Čuř́ik R. Histological types of basal cell carcinoma. Scripta Medica (BRNO) 2006;79(5-6):261-70.

11) Allen KJ, Cappel MA, Killian JM, Brewer JD. Basosquamous carcinoma and metatypical basal cell carcinoma: a review of treatment with Mohs micrographic surgery. Int J Dermatol 2014; 53(11):1395-403.

12) Kuijpers DI, Thissen MR, Neumann MH. Basal cell carcinoma: treatment options and prognosis, a scientific approach to a common malignancy. Am J Clin Dermatol 2002;3(4):247-59.

13) Rapini RP. Comparison of methods for checking surgical margins. J Am Acad Dermatol 1990;23(2 Pt 1):288-94.

14) Son SB, Seo SH, Son SW, Kim IH. Clinical findings and recurrence rate of 123 skin cancers treated with mohs microscopic surgery. Korean J Dermatol 2008;46(1):8-14.

15) Ducic Y, Marra DE, Kennard C. Initial Mohs surgery followed by planned surgical resection of massive cutaneous carcinomas of the head and neck. Laryngoscope 2009;119(4):774-7. 